\title{
Information communication technology learning through the broadband learning center to build 'Smart Community'
}

\section{Pembelajaran teknologi komunikasi informasi melalui pusat pembelajaran broadband untuk membangun 'Komunitas Cerdas'}

\author{
Nurul Ratna Sari \\ Department of Communication, Faculty of Social and Political Sciences, Universitas Airlangga \\ Address: Jalan Airlangga no 4-6, Surabaya, East Java 60286 \\ E-mail: nurul.ratnasari@fisip.unair.ac.id
}

\begin{abstract}
This research identifies the implementation of the Broadband Learning Center (BLC) program of the Surabaya government as a facility for community learning on Information Communication Technology (ICT). BLC is one of the crucial developments in building Smart Community as the main actor in Surabaya Smart City establishment. In the Surabaya context, BLC is one of the foundations in establishing a smart city which is an integration of three main dimensions, namely BLC as ICT facilities, community as the actor in smart city development, and the Surabaya government. The study applied a qualitative method with a descriptive research type - data collected through in-depth interviews, observations, and documentation studies. Interviews were conducted to 22 informants, which consisted of one BLC coordinator in government institution, one representation of BLC coordinator from community, and eight facilitators in five parts of the city areas which provided BLC facilities, and 12 representations of community groups as the users that consisted of adolescent and youth, women, and senior community. The observation was being held in BLC spots, while community learning activities occurred. The BLC remarkably facilitates community learning and education in dealing with ICT. The study indicates that the program performs ICT community learning which establishes community ability to understand and to use information from digital sources. However, it has been challenged by the conception of digital literation in boosting smart community active participation, which should enable the community to connect and interact with, also utilise the information. A socio-technical learning approach can be pertinently implemented by linking social and technological factors in order to fit the learning process and targeted community and also widen its opportunity in achieving smart community sustainability.
\end{abstract}

Keywords: ICT; learning community; digital empowerment; Surabaya Smart City; smart community sustainability

\begin{abstract}
Abstrak
Penelitian ini mengidentifikasi implementasi program Broadband Learning Center (BLC) pemerintah Kota Surabaya sebagai sebuah pengembangan fasilitas publik yang memberikan pelatihan berbasis Teknologi Informasi dan Komunikasi (TIK). Program BLC merupakan salah satu pendukung dalam membangun masyarakat yang cerdas (smart community) sebagai kunci dalam mencapai Kota Cerdas di Surabaya. Kota cerdas merupakan integrasi dari tiga dimensi utama yang harus terintegrasi. Dalam konteks penelitian ini, tiga dimensi utama dalam mencapai Surabaya sebagai kota cerdas adalah pemerintah kota Surabaya, BLC sebagai salah satu fasilitas TIK, dan masyarakat sebagai warga kota yang akan menjadi penggerak kota cerdas. Penelitian ini menggunakan metode kualitatif dengan tipe penelitian deskriptif. Pengumpulan data dilakukan melalui wawancara mendalam, observasi, dan studi dokumentasi. Wawancara mendalam dilakukan pada 22 informan, yang terdiri dari satu koordinator BLC dari Dinas Komunikasi dan Informatika pemerintah kota Surabaya, satu koordinator BLC dari masyarakat, dan delapan fasilitator yang mengajar di BLC, dan 12 informan dari masyarakat yang menggunakan fasiliats BLC dari kalangan pemuda, perempuan, dan usia lanjut. Observasi dilakukan pada lokasi penyelenggaraan BLC saat pembelajaran pada masyarakat sedang berlangsung. Data mengindikasikan bahwa BLC memfasilitasi proses pembelajaran dan edukasi pada masyarakat mengenai TIK bagi kelompok masyarakat pemuda, perempuan, dan usia lanjut. BLC merupakan pembelajaran masyarakat yang membangun kemampuan ICT dan kompetensi dalam memahami dan menggunakan informasi melalui sumber-sumber digital. Meskipun demikian, beberapa hambatan diantaranya komitmen dan partisipasi masyarakat perlu diantisipasi. Pendekatan socio-technical dapat diterapkan dalam proses pembelajaran dengan menghubungkan faktor social dan teknologi yang sesuai dengan masyarakat.
\end{abstract}


Konsep literasi digital yang membangun masyarakat cerdas yang sesungguhnya-tidak hanya mahir menggunakan internet secara teknis-untuk berperan secara aktif dalam membangun kota cerdas menjadi tantangan bagi pengembangan $B L C$.

Kata kunci: TIK; pemberdayaan digital; learning community; Surabaya kota cerdas; keberlanjutan masyarakat cerdas

\section{Introduction}

The emergence of Information and Communication Technologies (ICT) has evoked the discussion of the smart community regarding the smart city agenda (Albino et al. 2015:4). ICTs have been seen as a significant factor in shaping the smart city in urban community development. ICT responds to urban development through information technology implementation in a modern city (Albino et al. 2015). However, technological focus of smart city has been criticised as being too technical, while smart city concept necessarily covers not only the diffusion of the ICT but the quality improvement of people and community of life (Caragliu et al. 2011, Albino et al. 2015, Cocchia 2014, Neirotti et al. 2014). In the current era, the use of internet resources in many sectors demands not only digital community capacity but also digital literation. Smart city demands community learning and education that ICT enables community empowerment through digital empowerment aims at a better quality of life (Makinen 2006).

Surabaya is one of the big cities in Indonesia, which has established smart city notions in major living sectors, such as governance, business, and also vital sectors for the community such as economic and health (Surabaya government 2016). Establishing a smart city has been one of the city vision, which stated in the official government plan. Since 2006, ICT based on public services has been conducted aiming at e-governance for good governance. As a smart city, Surabaya acknowledged for hosting the International Smart City Forum in 2016 (Syarrafah 2016). In 2017, the city achieved a Smart City rating in Indonesia (Surabaya.go.id). In 2019, Surabaya is also nationally appreciated as a smart city based on National Smart City Index (Surabaya.go.id).

Some prominent cities in Indonesia develop smart cities for leveraging community life. Pertinently, the Surabaya Smart City concept has comprehensively performed as a learning city. Among smart cities in Indonesia, Surabaya is the only city from Indonesia that gains the award, together with 15 foreign cities. Surabaya has been awarded as The Best Practice Learning City by UNESCO in Cork, Ireland, in 2017 (Surabaya.go.id). Learning city as Surabaya Smart City concept aims at the smart community. It has implemented through several programs, mainly through the Broadband Learning Center (BLC). BLC is a public service that provides facilities for community digital learning. The facilities are located in every district in Surabaya to reach every community within the city. BLC aims at improving community learning and education through open and free digital learning access for Surabaya citizens. The digital disparity in the vary of community groups has been one of the government concerns in implementing the smart city. Thus, the program offers computer training, internet learning, Android learning, public services online applications, and also the internet for specific purpose training (e.g. internet marketing, blogging) for the community, who is willing to learn and adjust with digital devices and applications. Through BLC, the government performs in developing the smart city and smart community as it concerns at the community digital knowledge and learning through ICT facilities.

Remarkably, there are various definitions of the smart city. Some definitions specifically refer to the necessity of the community learning process for better community quality of life. Cocchia (2014) states that smart city mainly refers to knowledge, intelligence, and the digital city, which developed from ICT infrastructure, government policy, and human resources. Human resources are one of the smart city pillars. Additionally, Lombardi et al. (2012) state that smart city emerges through the application of ICT with on the role of human education, social and relational capital, and environmental issue; thus, human education is significant as the key to run the smart city. In the Indonesian context, Supangkat et al. (2018:169) also involve the human aspect as smart people, together with smart 
economy, smart governance, smart government, smart mobility, smart environment, and smart living. Supangkat et al. (2018:169) define the smart city as a city that has an excellent capability to manage all resources effectively and solve all problems efficiently using innovative, integrated, and sustainable solutions by delivering excellent city services to improve the quality of life. Therefore, smart people, which refer to the smart community, have urged the process of digital learning and education to take the role in achieving the smart city.

Regarding the human aspect, a smart city aims at the improvement of people's quality of life. Human dimension demands people, education, learning and knowledge as the main actors in a smart city. Borsekova et al. (2016) state that the community is an integral part of smart city development and sustainability. Human and social capital, along with the ICT infrastructure, significantly enables the sustainability of smart city development (Caragliu et al. 2011). In terms of sustainability, Makinen (2006) highlights the human aspect as a citizen-and community-oriented approach to utilise the information technology that aims at the quality of life improvement. There is extensive literature on the smart city; however, the connection between the smart city and smart community, particularly in community learning, has not widely addressed. Thus, the research question is how the implementation of the BLC program as Surabaya city's ICT development to build the learning community as one of the crucial parts of the Surabaya Smart City establishment. To gain an understanding of community digital learning for a smart city, this study would first identify the BLC as a community involvement program to support a community digital learning process in Surabaya. Secondly, the process of community learning in varies of community groups are discussed together with the implementations and impacts of the BLC program. The challenges of BLC as one of the digital empowerment efforts in enhancing the smart community in Surabaya would be addressed along with the implications of smart-learning city enactment through BLC.

\section{Research Method}

The study applied a qualitative method to comprehensively portray complex phenomena within its context (Bryman 2004). This study requires a case study approach that covers contextual conditions, not just the phenomenon of the study (Yin 2011). This research was limited to the Surabaya Smart City implementation as a learning city, mainly through the Broadband Learning Center as one of the facilities to develop community learning and education in the digital area. The data collected through in-depth interviews, observations, and documentation studies and semi-structured in-depth interviews conducted to 22 informants, that consisted of one BLC coordinator in government institution, one representation of BLC coordinator from community, and eight facilitators in five parts of the city areas which provided BLC facilities, and 12 representations of community groups as the users, which consisted of adolescent and youth, women, and senior community.

The number of the respondent was determined by the saturation point when the respondent provides homogenous data (Corbin \& Strauss 2008). The interviews were held face to face and in-depth to reveal respondents' awareness, experiences, and expectations of BLC program implementation by asking specific experiences that resulted in rich data collection. The observation was held in BLC spots while the learning activities conducted to experience the community's digital learning process. Additionally, the secondary resources were used to provide the broader context of the research (Bryman 2004). The data then transcript into a standard text. Reduction and categorisation were processed based on the theoretical framework of the research, which are a smart city as a learning city, smart community, digital empowerment, and literacy. During the process, this research allowed the themes to emerge from the interview result inductively. This stage refers to the analysis and interpretation process to gain a profound result of the research.

\section{Results and Discussion}

\section{Broadband Learning Center as a 'work-with' community program}

BLC program considered as the Surabaya government's effort to establish a smart, empowered community. The program aims at educating and empowering all Surabaya's community groups, such as adolescents, youth, adults, women, and senior community in this digital era. Previous research 
about BLC in Surabaya discovered that BLC is a community empowerment program that also supports the initiative of e-governance in Surabaya (Ariawantara 2017). This research discussed BLC in the context of e-governance implementation. It portrayed BLC as the integration of government policy and e-governance enactment. Another research in BLC Surabaya focused on the impact of BLC in relevant units within the city in achieving Surabaya Multi-Media City (Mulyasari \& Rosdiana 2017). The research put attention in the program outcome in individual, community, and institution in Surabaya. This research only focused on one particular BLC spot, which is BLC Dukuh Menanggal. The recent research about BLC also held mainly in the role of BLC in elevating career woman technological capabilities, specifically in BLC Wonorejo Surabaya (Iffah, Chasanah, \& Ilmi 2018). According to previous research about BLC in Surabaya, this research is distinctively linking BLC with the context of smart community as the key person in establishing Surabaya smart city. The gap of digital remains among populations that differ in socioeconomic status, educational background, gender, minority status, and age (Wilson, Wallin, \& Reiser 2003). On the other hand, ICT and digitalisation have emerged a smart city phenomenon that urges the availability of the smart community. Thus, this research concerns with the community digital learning to meet a sustainable smart community.

According to the data, the program appeared as a community education initiative that facilitated proper training to the community in a professional management scheme. BLC enables community roles as the program coordinator, facilitator, and beneficiaries. Under the supervision of the Surabaya government, BLC management run by the community representatives who meet the capacity requirement. The team which operates as coordinator and training facilitators should qualify in computer program, internet, android using, and internet for specific purposes. Significantly, they are also required to be professional instructors and facilitators who can handle a class dynamic based on community groups' characteristics. Regular evaluation conducted to both trainers and even trainees (personal interview with BLC coordinator and government representative) to meet the goals.

Remarkably, the government involves the community in developing the BLC program. The involvement conducted through regular coordination and evaluation with the BLC team, work performance measurement, and relevant skills training for the team (personal interview with government representative). Coordination session facilitates instructors to provide feedback to the government, as an input in developing BLC. The feedback based on their daily experiences in conducting digital learning in the community. During the session, the BLC facilitator would also be involve in the problem-solving process. The data indicates that despite general matters, some BLC spots have different challenges, which depend on the BLC facilities availability, community characteristic, and socio-cultural factors. Some examples of BLC development issues are the dynamic of community expectation, willingness, and commitment in being part of BLC implementation (personal interviews with BLC facilitator). Together with the coordinator and facilitators, the government sets alternatives in anticipating challenges.

The efforts of involving the community as BLC coordinator and facilitators have met the community empowerment stages, which are community hearing, consultation, education, and empowerment (Roberts 1995). According to Roberts (1995), community involvement refers to public participation in the decision-making process of an organisation. Through the stages, the BLC team, which consists of community representatives, participates intensively and actively in providing input, consulting alternatives, and proposing BLC development schemes. Additionally, the community team gains more knowledge and skills through competency training in conducting professional management, teaching methods, community involvement, and also service excellent delivery. Thus, they have a sense of belonging to develop the program and being responsible for the program's existence to contribute both to government and community (personal interview with BLC coordinator). The involvement of the community highlights community participation in community digital learning in the BLC initiative.

Based on the data, the BLC program carried out as community empowerment, which conducted through a community organising approach that presented as a 'work-with' community project. Community organising intents to a community change (Christens 2010), which demands community 
capacity such as leadership and active participation. In the context of Surabaya, the BLC appeared as a community empowerment program for the urban community. Adi (2008) stated that community in an urban area has different potential levels, developing stages, and characteristics, which may boost community actives roles in the empowerment. The urban community is potentially an adaptive community which encouraged to learn new knowledge and experience. Pertinently, the community should be the subjects, not objects, of the empowerment (Matthie \& Gunningham 2002, Sari 2016). Thus, community empowerment necessarily performed as a 'work-with' not only 'work-for' community project.

\section{BLC as a community digital learning and adjustment for innovation and problem-solving competence}

The research indicates BLC as a community digital learning and adjustment initiatives aiming at innovation and problem-solving capacity. BLC has facilitated community groups to learn about technology and digitalisation through periodic training available in every district of Surabaya. According to the interview with the community as the user, the program implementation benefited in terms of improving knowledge and ability in using computers and the internet, providing more opportunities for self and community development, and also supporting community adjustment to the use of technology in any aspects of life. The community also stated that BLC encouraged them to create innovation and problem solving relevant to their daily life. Importantly, innovation and solving problems are the main features of community intelligence (Komninos 2002, Komninos 2006) to be a smart community.

Specifically, The data reveals that adult women learned in BLC had been benefited in many aspects, such as economic, social, and health. Economically, some of them, particularly housewife, has been motivated and enabled to apply online marketing. It created an entrepreneurship opportunity. Socially, they apply a computerised database for community activities such as arisan - a regular community gathering event, particularly for adult women, which required money collection to be paid back to the member in turn. The use of a computer program by finance data and member database has performed accountable management and increase trustworthiness within the member. While in health and family aspects, women get used to learning about the healthy menu, parenting guidelines, family stuff, such as the tips in 'Do It by Yourself' and learning material for child education from online resources. All of these indicate that BLC has built women's community capacity in ICT. Additionally, BLC has empowered them in terms of creativity and problem-solving ability by using digital devices.

However, some informants from the women community group stated that learning ICT had been a challenge for them, particularly in understanding the specific terminology in a computer program. Interestingly, BLC facilitators would link digital terminology with their daily and local vocabulary in delivering the learning material. One example is a mouse (one of the computer tools for clicking) explained as 'uleg-uleg', a traditional cooking tool that commonly used in making spicy food. Other facilitators began the training by exploring their habits and daily activities to connect with the learning material, such as arisan and household stuff. These have indicated the need for a sociocultural approach in digital learning and literacy, as stated by Lankshear \& Knowbel (2008) that there are pluralism and diversity in literacy process that should be fit with the learner. Learning and literacy should engage learners in experiences that relevant to their socio-cultural background. Thus, there are various of literacy schemes which necessarily match with community groups.

Turning to adolescent, most of them learned about computer programs such as Microsoft Word, digital design programs, photoshop, and also social media. They also learned about school subjects on the internet. However, while learning the internet in BLC, they preferred to play games and access social media. It has urged the demand for adolescent and youth empowerment in BLC practices. The program needs to take a role in youth empowerment (Groark 2013) through digital learning. Youth empowerment is relevant to self-actualisation in encouraging youth potency and active participation aiming at community leadership (Groark 2013). In the BLC context, the program has the opportunity 
to promote positive activities for children and youth by learning ICT that has become part of their life. It potentially leveraged by community leadership approach that enables youth to contribute to their community through positive self-actualisation. Technology and digitalisation can be a tool in supporting the positive contribution of youth to the community (Suyatna \& Nurhasanah 2017).

Another concern in adolescents is the necessity of digital literacy. Gee in Lankshear \& Knobel (2008) stated that digitalisation had widened the literacy gap in more affluent and more deprived children in terms of their productive opportunities in learning and success in today's society. Technology has opened more opportunities, yet it requires skills and capacity to achieve that. Additionally, Gee in Lankshear \& Knobel (2008) also stated that technology access for children should be equipped with adult mentoring and productive learning system. Thus, digital capacity is the foundation of digital literacy. BLC, as a digital learning facility for children, should develop a productive learning system that aims at children and youth empowerment.

Additionally, BLC also facilitates older citizens to learn about digital media. Even though most of them are retirements, they have high enthusiasm for updating new knowledge relevant to ICT and acquiring technology competencies. In this context, BLC takes roles in a community adjustment process, particularly in linking the gap of the senior generation with technology. Most of them realised that digitalisation is a challenge. However, they believe that they can deal with it by learning. The community also expects the BLC team, particularly training instructors, to be patient and show more empathy to their condition, as a generation who previously had never been in touch with technology.

Furthermore, the senior community learning vibrant is the principal capital in their learning process. According to these statements, the senior community should become one of the main empowerment targets in meeting digital disparity. It is since the older community did not grow up in the Information Era; thus it becomes one of the factors that results in their inability to draw on the existing skills and competencies required to learn ICT applications (Beisser 2005:3). Technology has transformed many aspects of life, such as public services (Beisser 2005), communication activities, and information sharing. The circumstances are different from the ones in the previous era. Thus, the older generation must learn techniques to maintain their existence in the community.

Overall, BLC has emerged a learning community in all population groups. It is an asset in developing smart cities and smart communities. Thus, learning vibrant is necessarily embraced in a city in responding to rapid changes in today's life (Longworth 2006). A city with learning commitment aims at sustainability, which is the outcome of a smart city. Longworth (2006) noted that learning the city is the umbrella of the sustainable smart city which covers three main dimensions; 1) economic, 2) environmental, and 3) social. These dimensions refer to the significant area to respond in order to build a sustainable city. Additionally, Cocchia (2014) also highlighted these three dimensions in developing a smart city in terms of the actors and their roles consisting of technology, people, and government commitment. Linking the concept of learning the city and smart city, these three main actors have their roles respectively to meet the sustainability in economic, environmental, and social aspects.

\section{BLC challenges: Covering digital capacity and digital literacy}

As a program that aims to build community competence in using digital devices, BLC has challenged by the conception of digital literation in boosting smart community. Digital literation should not only enable the community to connect and interact with, but also provide the facility to implement the information. The change in how human pursue information, communicate and create as members of the global community has urged BLC to take the role in digital literacy. Thus, community digital empowerment demands not only digital community capacity but also digital literacy.

Concerning digital literacy, Lankshear \& Knobel (2008) explained it is possible to apply the sociotechnical learning approach which integrates the education process with learning principles in terms of digital devices. This approach implements digital literacy through social and cultural practices of the community. It refers to penetrate technology or digital activity into the popular culture, for 
instance, a workplace blogging and participation in online network sites for workers community. Everyday life experiences can be a source of learning which can appropriately be linked with the type and character of the community. Socio-technical learning is an urgent agenda in BLC implementation to achieve digital learning sustainability. Community technological capacity can be optimised by its ongoing learning process in their daily activities which provides real digital learning experiences.

In order to meet digital literacy in a smart city, people aspect plays a significant role as the key person in achieving smart city (Cocchia 2014). In line with this statement, Borsakova et al. (2016) highlighted that the power of community in smart urban development is an asset in developing smart and urban community. Widyaningsih (2013) highlighted that the smart city establishment in Surabaya has been implemented holistically, not only by building ICT infrastructure but also strengthening social capital. Community is the main people and social capital in running a smart city. Thus, community commitment in a learning process is essential because learning aims at a long life outcome.

Furthermore, community leadership in terms of digital literacy should be improved together with community action. In the context of BLC, the government and team are required to be aware of factors that influence community learning habits to create a proper training scheme aiming at digital literacy. As stated by the coordinators, community commitment to learning depends on some factors, such as their needs in digital learning. Some of them participate actively to get benefits from new knowledge and experiences, while some others join the program to have an activity that may result in low commitment in learning. In relevant to community leaderships aiming at the smart city, Hayati et al. (2017) noted that there are potencies in Surabaya local community which shown by local innovation and creativity in kampung settlements that support the concept of the smart city. The community in Surabaya has multiple unique characteristics (Hayati et al. 2017) that can be cultivated in terms of community leadership and role in BLC for the smart city.

Furthermore, as a community to a community program, social engagement in BLC is a necessity to build a relationship between the instructors and the participants of the community (Beisser 2005). A positive relationship in learning should present commitment, motivation, and encouragement. Susanti et al. (2016) discovered that perception and experience are the keys to engage the community in building a smart city. In the BLC context, positive and inspiring interaction, and various activities in BLC may shape community positive perception and experience to boost their contribution to Surabaya smart city settlement. Pertinently, BLC training is required to contribute to the society by social impact in economic, environmental, and social aspects in order to meet a learning city (Susanti et al. 2016, Longworth 2006). Thus, the BLC role in digital literacy and community action should be an urgent agenda in order to meet a smart community and city of Surabaya.

\section{Conclusion}

BLC has performed community digital learning which establishes the community's ability to understand and to use information from digital sources. BLC in Surabaya smart city indicates community empowerment which implements a "work-with" community program to support community digital learning process in Surabaya. The program facilitates community groups learning, such as adolescent and youth, women, and senior community. Technology and digital learning have benefited the community in terms of improving knowledge and ability in using computers and the internet, providing more opportunity for individual and community development. Thus, BLC also has a role to support community adjustment to the use of technology in many aspect of life, which results in problem-solving capacity.

Remarkably, the BLC program has been challenged by the conception of digital literation in enabling the community to connect and interact with, and also implementing information. As a "work with" community program, BLC is necessary to concern about community aspects that influence smart city achievements, such as community commitment in learning, community leadership, and community action in digital literacy. Thus, BLC should leverage its role in digital disparity through digital literacy and community action in transfer learning. Additionally, a socio-technical learning 
approach can be implemented in order to fit the learning process and the targeted community, and also widen its opportunity in achieving smart community sustainability. Thus, digital learning and literacy should anticipate a widening gap in digitalization era. Simultaneously, this research provides insights for governments seeking to build a brilliant community through a community learning in this information age within a smart city, in a developing country context.

\section{References}

Adi I (2008) Intervensi Komunitas: Pengambangan Masyarakat sebagai Upaya Pemberdayaan Masyarakat. Jakarta: Rajawali Pers.

Albino V, Berardi U, \& Dangelico R (2015) Smart Cities: Definitions, Dimensions, and Performance. Academic research paper.

Ariawantara P (2017) Peran Broadband Learning Center dalam community development. Jurnal Masyarakat Kebudayaan dan Politik 30 (2):162-173. https://doi.org/10.20473/mkp. v30i22017.162-173.

Beisser S (2005) Empowerment through service-learning: Teaching technology to senior citizens. The Innovation Journal: The Public Sector Innovation Journal 10 (1):1-12.

Borsekova K, Vanova A, \& Vitalisova K (2016) The power of community in smart urban development. Procedia Social and Behavioral Sciences 223:51-57. https://doi.org/10.1016/j. sbspro.2016.05.289.

Bryman A (2004) Social Research Methods. 2nd ed. New York: Oxford University Press.

Caragliu A, Del Bo C, \& Nijkamp P (2011) Smart cities in Europe. Journal of Urban Technology 18 (2):65-82. https://doi.org/10.1080/10630732.2011.601117.

Christens B (2010) Public Relationship building in grassroots community organising: Relational intervention for individual and system change. Journal of Community Psychology 38 (7):886-900. https://doi.org/10.1002/jcop.20403.

Cocchia A (2014) Smart and Digital City: A Systematic Literature Review. Smart City, Springer International Publishing Switzerland.

Corbin J \& Strauss A (2008) Basics of Qualitative Research (3rd ed.). Thousand Oaks, CA: Sage.

Groark L (2013) Youth empowerment, engagement and identity: A Participatory Action Approach to exploring marginalized youth perceptions of their role identity and the effects on civic engagement. Master thesis, Westminster College.

Hayati A, Bararatin K, Utami S, Septanti D, Santosa H, Weichart G, \& Valent K (2017) From Smart Living into Smart City: A Lesson from Kampung of Surabaya. Paper presented in Seoul World Architects Congress.

Iffah N, Ilmi N, \& Chasanah K (2018) The role of Broadband Learning Center in elevating career woman technological capabilities: Study in Wonorejo, Surabaya. Proceedings of the 2nd International Conference on Education.

Komninos N (2002) Intelligent Cities: Innovation, Knowledge Systems and Digital Spaces. Routledge: London.

Komninos N (2006) The architecture of intelligent cities. Intelligent Environments, Institution of Engineering and Technology, pp. 13-20. Paper presented in 2nd International Conference on Intelligent Environments.

Lankshear C \& Knobel M (2008) Digital Literacies: Concepts, Policies and Practices. New York: Peter Lang Publishing.

Longworth N (2006) Learning City Dimensions. Pascal Associate.

Lombardi P, Giordano S, Farouh H, \& Yousef W (2012) Modelling the smart city performance. The 
European Journal of Social Science Research 25 (2):137-149. https://doi.org/10.1080/1351 1610.2012.660325.

Makinen M (2006) Digital empowerment as a process for enhancing citizens' participation. ELearning 3 (3):381-395. https://doi.org/10.2304/elea.2006.3.3.381.

Matthie A \& Gunningham G (2002) From Clients to Citizens: Asset-Based Community Development as a Strategy for Community-Driven Development. Occasional Paper Series (4th). Canada: the Coady International Institute.

Mulyasari M \& Rosdiana W (2017) Dampak program Broadband Learning Center (BLC) di kelurahan Dukuh Menanggal, Kecamatan Gayungan, Kota Surabaya. [Accessed 2 October 2019]. file:///C:/Users/hp/Downloads/21292-25314-1-PB.pdf.

Neirotti A, De Marco AC, Cagliano G, Mangano F, \& Scorrano (2014) Current trends in Smart City initiatives: Some stylised facts. Cities 38:25-36.

Roberts R (1995) Public involvement: From consultation to participation. In: F Vanclay \& DA Bronstein (eds). Environmental and Social Impact Assessment, pp. 221-246. England: John Wiley \& Sons, Ltd.

Sari N (2016) Community as the actor in empowerment: The role of Community Information Group of Surabaya in building well-informed community. Paper presented in International Conference on Education \& Social Science (UK-ICESS) "Educational and Social Issues in the Changing Asia".

Supangkat S, Arman A, Nugraha R, \& Fatimah Y (2018) The Implementation of Garuda Smart City Framework for Smart City Readiness Mapping in Indonesia. Journal of Asia-Pacific Studies (Waseda University) 32:169-176.

Surabaya government (2016) RPJMD Kota Surabaya 2016-2020. Surabaya government.

Surabaya government (2019) Penghargaan Index Kota Cerdas Indonesia diraih Surabaya. [Accessed 4 March 2019]. https://www.surabaya.go.id/id/berita/50028/penghargaan-indeks-kota-cerdas.

Susanti R, Soetomo S, Buchoria I, \& Brotosunaryo P (2016) Smart growth, smart city and density: In search of the appropriate indicator for residential density in Indonesia. Social and Behavioral Sciences 227:194-201.

Suyatna H \& Nurhasanah Y (2017) Sociopreneurship sebagai tren karir anak muda. Jurnal Studi Pemuda 6(1):527-537. https://doi.org/10.22146/studipemudaugm.38011.

Syarrafah M (2016) Surabaya tuan rumah Forum Smart City 2016. Tempo.co.id. [Accessed 10 July 2018]. https://nasional.tempo.co/read/788816/surabaya-tuan-rumah-forum-smartcity-2016/full\&view $=$ ok.

Widyaningsih D (2013) Kota Surabaya menuju smart city. Electronic theses and dissertation. Universitas Gadjah Mada. [Accessed 2 October 2019]. http://etd.repository.ugm.ac.id/index. php?mod=penelitian_detail\&sub=PenelitianDetail\&act=view\&typ=html\&buku_id=63560.

Wilson K, Wallin J, \& Reiser C (2003) Social stratification and the digital divide. Social Science Computer Review 2 (2):133-143.

Yin RK (2011) Application of case study research. 3rd ed. United States of America: Sage Publications. 